\section{ECONOMICS}

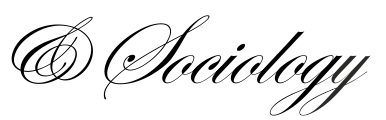

Appiah, M. K., Possumah, B. T., Ahmat, N., \& Sanusi, N. A. (2019). Small and medium enterprise's internal resources and investment decisions in Ghana: The resource-based approach. Economics and Sociology, 12(3), 37-53. doi:10.14254/2071789X.2019/12-3/3

\title{
SMALL AND MEDIUM ENTERPRISE'S INTERNAL RESOURCES AND INVESTMENT DECISIONS IN GHANA: THE RESOURCE-BASED APPROACH
}

\begin{abstract}
Michael Karikari Appiah, School of Social and Economic Development, Universiti Malaysia Terengganu, Malaysia Email: kofikarikari@yahoo.com
\end{abstract}

Bayu Taufiq Possumah, School of Social and Economic Development, Universiti Malaysia Terengganu, Malaysia

Email:bayu@umt.edu.my

\section{Nizam Ahmat, School of Social and Economic Development, Universiti Malaysia Terengganu, Malaysia \\ Email:nizamahmat@umt.edu.my \\ Nur Azura Sanusi, School of Social and Economic Development, Universiti Malaysia Terengganu, Malaysia \\ Email:nurazura@umt.edu.my}

Received: April, 2019

1st Revision: July, 2019

Accepted: August, 2019

DOI: $10.14254 / 2071-$

789X.2019/12-3/3

JEL Classification: D02, O17, P31
ABSTRACT. We report new evidence on Small and Medium Enterprises' (SMEs') internal resources, i.e investment capital, business stability, customer size, type of ownership, legal status, industrial structure and location on investment decisions in the Ghanaian oil and gas sector between 2016 and 2017. Overall, we find that SMEs of larger business size, with large investment capital, large fixed assets, more business stability, structured business ownership, large customer size, registered status, operations in urban locations and reinvested annual profits -- are more likely to invest in Ghanaian oil and gas sector. Per contra, the results reveal that industrial structure has no influence on SMEs' investment decisions. Additionally, our findings are most robust to SMEs that choose to invest in the oil and gas value chain which is consistent with the resource-based theory. This empirical study has been conducted through a survey. Data has been collected using a stratified sampling technique and structured questionnaires with 245 SMEs across diverse industries. The survey data has been analyzed using binominal logit regression and Chisquare test. The results are expected to be of substantial importance for investment decisions in the domestic business environment. We strongly recommend the replication of this study in other emerging oil and gas economies.

Keywords: investment, oil \& gas, Ghanaian SMEs internal resources, Logit model 


\section{Introduction}

Over $95 \%$ of the enterprises across the world are SMEs although precise up-to-date data are yet to be established. In the furtherance of SMEs contributions, approximately $70 \%$ of GDP is accounted for by SMEs, particularly in Sub-Saharan Africa (SSA) and Asia. SMEs are equally important for their role in human capital development (Abor \& Quartey, 2010; Ayyagari, Demirgüç-Kunt \& Maksimovic, 2011; Quartey, Turkson, Abor \& Iddrisu, 2017). These figures are supposedly higher when the informal SMEs are considered as reported by the World Bank Group (WBG) in 2015. Meanwhile, available evidence suggests that an estimated 600 million jobs are needed from now till the next 15 years to absorb the ever-increasing workforce, particularly in SSA and Asia. SMEs are said to have the exertion to create 4 out of 5 new formal jobs positions within the emerging economies.

The WBG asserted that SMEs by number dominate the world business stage. Accordingly, the Economist Intelligence Unit (EIU) 2010) reported that Japan has the highest proportion of SMEs among industrialized countries in the world, accounting for more than 99 percent of all enterprises. In 2009-2010 Australia SMEs contribute about 60\% of the industrial value added (Australian government, 2011). In the Organization for Economic Communities Development (OECD) economies, SMEs account for more than $95 \%$ and contribute roughly $55 \%$ of GDPs. Similarly, the International Trade Commission (2010) of the United States reported that SMEs contributed about $50 \%$ of the country's non-agricultural GDP in the year 2004 alone. The services sector reportedly accounted for $79 \%$ of the SMEs contribution during 1998-2004.

The EU-27 back in 2012 duly acknowledged the significance of SMEs and avowed that this sector accounted for $99.8 \%$ of all enterprises, generating $67 \%$ of employment and contributing 58\% of the Gross Value Added (GVA). In 2015 the EU affirmed the contribution of SMEs and avowed that this sector generated $€ 3.9$ trillion in value added and employed 90 million people. In the year 2015 alone SMEs were reported to have accounted for two thirds of the total employment and three fifths of the value added within the EU. Dalberg (2011) averred that although SMEs appear to dominate the high-income economies, SMEs are also of socioeconomic importance to the middle and low-income countries, contributing significantly to their GDP and employment. Moreover, SMEs contribute to the most innovative works through collaborations with the larger sector.

Avalanches of previous studies (Kazimoto, 2014; Farsi \& Toghraee, 2014; Bouazza, Ardjouman \& Abada, 2015) reported mixed results between SMEs internal characteristics and investment decisions. Although whopping majority of the previous studies (Bouazza, Ardjouman \& Abada, 2015; Quartey, Turkson, Abor \& Iddrisu, 2017; Appiah, Possumah, Ahmat, \& Sanusi, 2018a, 2018b, 3018c) reported positive and significant association between internal firm factors and investment decisions, negative and insignificant results had also been moderately reported (Khaled, 2012; Ayyagari, Demirgüç-Kunt \& Maksimovic, 2011; Possumah and Appiah, 2018). The reasons accounting for variations in the previous results can be attributed to: (1) different methods, different SMEs internal variables and different measures of investment decisions used in them. (2) Previous studies determined SMEs' investments decisions under different contexts such as industries, countries and time periods. (3) Other owner/manager-specific constraints might have resulted in these varying results in the previous studies.

The aims of this paper are as follows: (1) to measure the associations between WTI in high-value oil and gas sector and SMEs' internal characteristics (business size, investment capital, fixed assets, business stability, business ownership, customer base size, industrial 
structure, business location, legal status and reinvestment of annual profits); (2) to make predictions using SMEs internal characteristics and control for WTI.

The paper is organized into five sections as follows. The importance and purpose of the research are presented herein (section 1). Section 2 presents the theoretical orientation and empirical review including the proposed research model and hypotheses; section 3 presents the methodology, including study setting, population, sampling, model estimation, data collection and data analysis. Section 4 presents the results obtained from data analysis, the chi-square analysis and binomial logistic regression. Finally, in Section 5 we present the discussion, conclusions and limitations of this paper as well as implications for future research.

\section{Literature review}

\section{Theoretical Orientation}

The deployment of the firm's internal resources as the basis for investment decisions can be traced into the Resource-Based View (RBV) Theory by Beiger Wernerfelt in 1984. The RBV model stipulates that the inherent strategy requires from firm to achieve a competitive strategy are found in the bundle of productive resources at the firm's disposal and how these resources inform investment decisions, growth and performance. The RBV model overly relies on the internal perspective of firms to illustrate how business firms gain a sustained competitive advantage over competitors (Conner, 2002). The RBV model contrast with the school of thought of an external market or the industry level view of comparativeness such as the virtuoso Michael Porter's five competitive forces framework which is one of the quintessences of the neoclassical economics. The RBV model drawls on so many schools of thought- including the traditional, competitive and contemporary. The RBV model is applied in this study due to the importance the model places on the internal strength of firms based on their unique resources available to them.

Our study focused on the applicability of RBV theory to explain the odds of SMEs investing in the Ghanaian oil and gas sector. Therefore our selection of SMEs internal factors such as location, size, investment capital, business stability, customer size, type of ownership, legal status and business sector to determine investment decisions is consistent with Wernerfelt RBV theory. In this view, the unique value-creating resources of the firms could be transformed into a sustainable competitive advantage which acquisition or imitation wouldn't be penetrable. It is based on this wisdom that this study stipulates that SMEs WTI in the Ghana oil and gas sector will be informed by some of the unique internal resources outlined in the RBV model. However, the only snag associated with this model is the firm's ability to maintain and protect the combination of their unique resources so that cannot be easily imitated by competitors. Early researchers (Barney, 1991; Dierickx and Cool, 1989; Peteraf, 1993; Rumelt, 1984) have previously explained these unique internal resources that differentiate one firm from the other.

\section{Internal Firm Characteristics and Investment Decisions}

SMEs internal characteristics in relation to their growth, performance and investment decisions have been adequately researched (Kazimoto, 2014; Farsi \& Toghraee, 2014; Bouazza, Ardjouman \& Abada, 2015; Quartey, Turkson, Abor \& Iddrisu, 2017; Appiah, Possumah, Ahmat, \& Sanusi, 2018). For instance, Kengatharan and Clamenthu (2017) determined the relationship between capital investment practices and investment decisions of manufacturing companies. The study found significant and positive relationships between present value, internal rate of return and investment decisions. Moreover, the study reported that the 
designated professional body had a significant and negative association with investment decisions. Meanwhile, risk analysis had an insignificant relationship with investment decisions.

Moreover, Narayansamy, Mohd-Rashid \& Hashemoghli (2012) examine the current practices and the classical venture capital decision model and reported significant similarities between decision making procedure and investment criteria needed to select investment with the classical model. Plaziak \& Szymansk (2014) assessed the importance of choosing a business location. The study found that business location is a very important factor to consider when setting up a business noting that in addition to other critical factors such as investment requirement and investment climate attraction. Business location is a major determinant of investment decisions. Bakar \& Yi (2016) examined the relationship between geographical location and demographic characteristics by considering the impact of the psychological factors on investor's decisions making. The study found that overconfidence, availability bias and conservatism exerted a significant effect on investors decisions. Meanwhile, herding behaviour has an insignificant impact on investment decisions.

Sequel to the above, Bialowolski \& Weziak-Bialowlska (2013) examined the business size and investment decisions and reported a strong association between business size and investment decisions. Lai, Yung-Lung, Feng-Jyh \& Lin, (2015) determined the relationship between company size and investment decision and found that company size is among the important factors that affect corporate investment decisions. Lutter (2008) and Keloharju, Knupfer \& Linnainmaa (2012) reported on how customer size affects product to market and investment decisions. Kopitov (2013) and Crum\& Nelson (2015) revealed that business stability has an effect on long time investment. These studies further reported that property right encourages entrepreneurs to invest in new ventures. Nasrum, Akal, \& Tenri (2013) examined the relationships between ownership structure and corporate investment decisions. This study found that have the significant positive effect of ownership structure and corporate investment decisions. Again, Chen, Guedhani, Ghoul \& Wang (2014) studied the role of ownership structure in the firm's investment decisions and efficiency. This study found an effect of ownership type on firm-level capital allocation and further reported that foreign ownership investment and efficiency is stronger when government institutions are weaker.

Dragnić (2014) reported that internal factors such as business entity size, technology, life cycle stages, product innovation, and organizational features of autonomy, centralization and formalization and market roles exert a significant impact on SMEs performance in terms of sales growth and goals achievement. Relatedly, Kira \& He (2012) found that SME's location, size, age, industry, business information, incorporation and collateral affect access to debt finance. Sarwoko, Surachman, Armanu, \& Hadiwidjojo (2013) investigated the influence of entrepreneurial characteristics and competencies on SMEs performance and reported that entrepreneurial characteristics have significant effects on firms' performance. More so, entrepreneurial competences moderate the relationship between SMEs characteristic and performance. Sarwoko, Surachman, Armani, \& Hadiwidjojo indicated that change entrepreneurial characteristics significantly affect the firm's competencies.

Moreover, Kozubíková, Belas, Bilan \& Bartol (2015) assessed the relationship between personality characteristics and approach perception and management of business risk, the study found the most significant risk in business is the market risk which significantly affects the performance of the business. Also, the characteristics of entrepreneurs influence their knowledge of lending and credit risk. The study further opined that entrepreneurs shown a high level of confidence and optimism towards credit risk assessment and financial management. Becherer, Halstead \& Haynes (2001) examined market orientation in relation to SMEs characteristics including managerial style and background of the company president and reported that the size of the firm does not have a stronger association with market orientation. 
However, the ability to develop and sustain the required corporate culture and infrastructure may be very cumbersome to achieve in smaller firms than medium or large scale firms. Meanwhile, market orientations have a positive association with the day-to-day decision making of smaller businesses than the large companies because the latter may require involvement, however, such an involvement may be prevented in the case of small companies. The responsiveness also takes a similar approach as the case of the involvement.

Ciavarella, Buchholt, Riordan, Gatewood \& Stokes, (2004) corroborated the work of Pasanen (2007) when reported that the stability of the entrepreneurs and their inherent characters may have massive effects on their growth tendencies. Sidika (2012) opined that the strength of SMEs specific characteristics influences their growth. These include; age, gender, motivation, experience, risk-taking propensity, educational background and preference for innovation (Pasanan, 2007; Sidika, 2012). The top management team and managerial characteristics of SMEs are part of the key factors that affect SMEs growth. Olawale \&Garwe (2010) postulated that small firms can be made more efficient by focusing on inherent managerial capabilities such as knowledge and set management capacities are sets of knowledge and skills (Aylin Garango, Cocca, \& Bititchi 2013; Singh, Garg \& Deshmukh 2008). Morse Fowler \& Lawrence (2007) technological capabilities benefit SMEs in several ways: they enhance SME efficiency, reduce costs, and broaden market share, both locally and globally.

Pullen, de Weerd-Nederhof, Groen, Song \& Fisscher (2009) examined the patterns of internal SMEs characteristics that affect innovation performance. The study revealed that companies with incremental innovation share a common pattern in their internal business due to high overall innovation performance. Therefore organizations with analyser strategy and adhocracy culture are most likely to achieve high innovation performance. Kozlowski \& Matejun (2016) reported that the success of project management in SMEs depend largely on such factors as focused on the search for new resources, efficiency geared approach, a new technology which serve as enablers of SMEs growth and development.

Blackburn, Hart \& Wainwright (2013) studied factors that influence SMEs performance and growth, this study revealed that size and age are the most dominant factors when dealing with factors affecting SMEs performance particularly growth. Moreover, the business plan was also reported to have a significant effect on SMEs performance. Blackburn, Hart \& Wainwright further argued that both enterprise structure and managerial characteristics are significant in determining the growth and performance of SME. The authors, however, cautioned that the owner-manager characteristics are very important. Pasanen (2007) argued that there are different measures of enterprise growth and development. These may include the mindset and personality of the owner-managers. Moreover, factors such as education, age, gender, family background, and capability may be considered when determining SMEs growth. Furthermore, the personal growth aspirations of the owner-manager may also affect the successful outcome of the SME.

In Nigeria, Eze, Okoye, Nebo, Ohakwe, Chukwuemeka \& Anazodo (2011) investigated the characteristics of SMEs managers towards IT adoption focusing on characteristics such as age, education, experience and gender. The authors found that age and educational attainment have a strong influence on IT adoption behaviour. Meanwhile, gender and work experience have no significant effects. Sidika (2012) asserted that the success or failure of SMEs depends on its internal characteristics and many other key strategies rather than the external environment. Moving on the author further suggested that the SMEs characteristics have received a number of exertions with mixed results on SMEs growth and development. Meanwhile, available evidence shows that the SMEs characteristics have more positive and significant effects on growth as compared to the insignificant outcome. In Algeria, Bouazza, 
Ardjouman \& Abada (2015) examined the internal factors of SMEs that are responsible for the unstable and limited growth of SMEs. The authors postulated that factors such as unfair competition from the informal sector, investment capital, lack of external access to finance, lack of access to internal real estate, cumbersome and costly bureaucratic procedures, burdensome laws, policies and regulations, low human resource capabilities are the major factors affecting SMEs growth. Accordingly, the authors argued that SMEs are the main strength of the country's economy despite the fierce and unfavourable environmental influence.

Al-Matari, Al-Swidi \& Fadzil (2014) asserted that financial management capabilities are very necessary to ensure proper controls both internal and external. There is a notable lack of research in developed as well as developing nations regarding the direct association of internal audits functions and firm performance. More specifically, among these few studies is the one conducted by Al-Matari Al-Swidi \& Fadzil (2012) who investigated the association between the board characteristics and performance of Kuwaiti firms. They called for future researchers to examine the relationship between internal audit and firm performance, both directly and indirectly, or in light of a moderating effect. From the empirical reviews presented herein. The present study had developed a new research model to estimate the impact of internal firm characteristics on SMEs WTI in the Ghanaian oil and gas sector as shown in Figure 1.

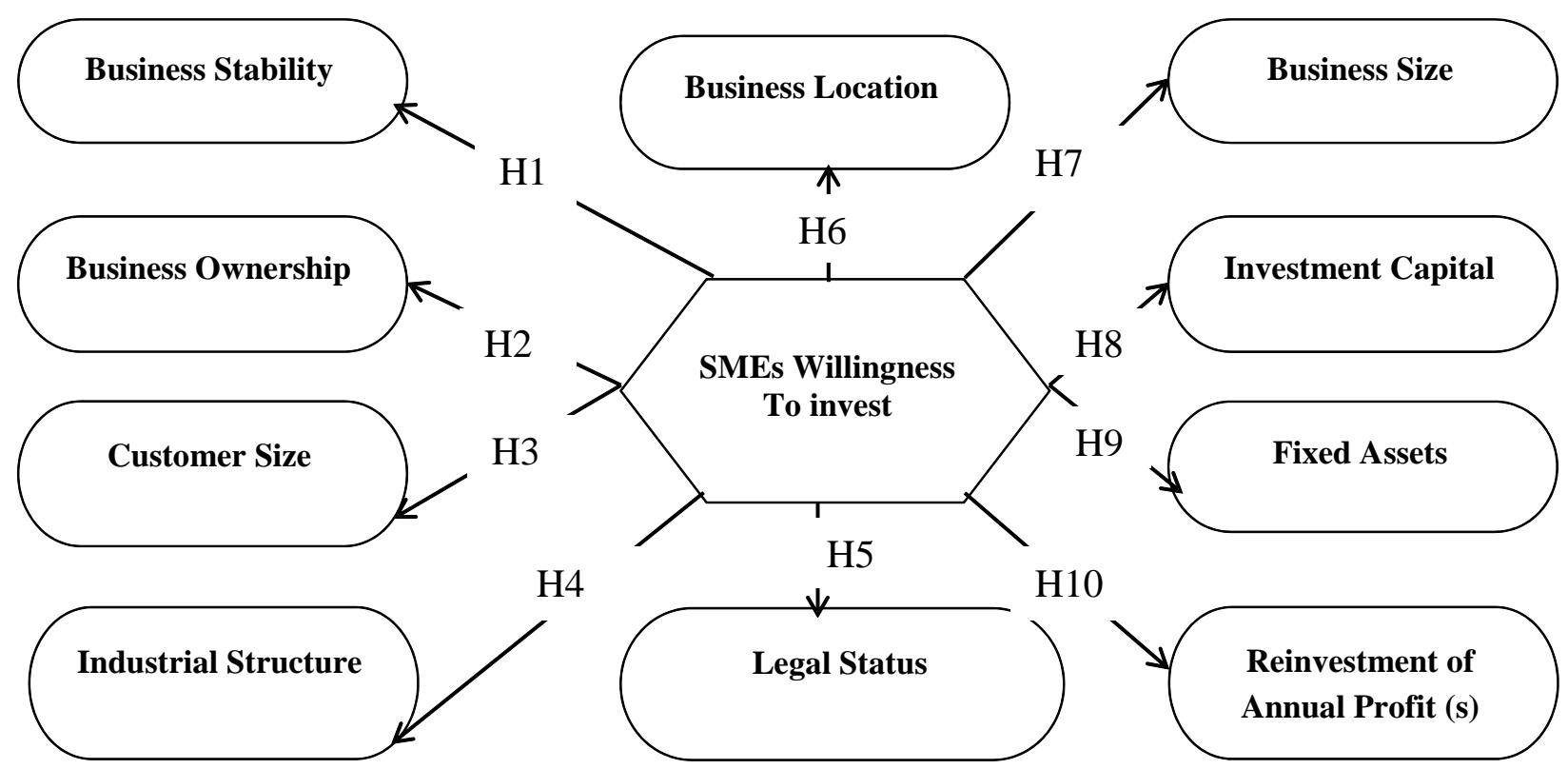

Figure 1. Theoretical Framework and Proposed Hypotheses

Source: Authors Construct

\section{Research methodology}

\section{Research Design}

The quantitative research design is employed in this study. Quantitative design involves the use of numbers and estimations to measure the degree of occurrence. This design also has the following attributes; a collection of numerical data, it's based on positivism and objectivity conception of social reality (Fox \& Bayat, 2007). In view of this numerical data are gathered to measure SMEs WTI in the Ghanaian oil and gas sector. Moreover, this study is classified as explanatory research. This is because the researchers aim is to examine cause- and- effects 
relationships. The explanatory design has been employed in our study to examine the relationship between SMEs internal characteristics and WTI in the Ghanaian high-value oil and gas sector.

\section{Population and Sampling Design}

The study is conducted in the natural settings of the SMEs hence it is non-contrived. The population of the study was made up of SMEs registered with the National Board for Small Scale Industries (NBSSI) in Ghana. Specifically, SMEs within the following categories were considered: manufacturing, retailing and service. Regarding population sampling, two main categories are known. Namely; probability and non-probability sampling- the former provide zero chance of been included in the study whereas the later chooses a specific member of the population to be included in the study. Using the rule of ten (10) as a guiding principle as recommended by Hair et al. (2014) as cited in Possumah et al.. (2018) 100 cases were the minimum requirement for the study. Meanwhile, 245 questionnaires were administered to the SMEs out of which 147 useable questionnaires were received representing a $60 \%$ response rate. Stratified sampling technique was used -which forms part of the probability (randomization) sampling (Zikmund, Babin, Carr \& Griffin, 2012). Subsequently, the target population was divided according to the major sectors of the SMEs industry. Notably; Service, Retailing and Manufacturing. The Stratified sampling technique is considered more effective due to its ability to drastically reduce sampling errors and also ensures greater representatives

\section{Data Collection and Analyses}

The data for the study were predominantly primary corrected between December 2016 to May 2017. Primary data are gathered with the use of structured questionnaires. When research studies involve quantifiable attributes the survey by questionnaire is particularly required. Every research can be broadly categorized under any four (Saunders, Lewis \& Thornhill, 2012; Zikmund, Babin, Carr \& Griffin, 2012). Although individuals answered the questionnaire the unit of analysis for the study is organizational level. This study is a crosssectional since the time consideration is given to the present situation, unlike longitudinal studies which usually requires a long time period. The primary data are analysed with the aid of Statistical Package for Social Sciences (SPSS) version 23. Precisely, chi-square and binary logistic regression analyses are carried out. All the proposed hypotheses are tested at 0.01 and 0.05 significance levels. The variables used in the model estimation had been presented in Table 1.

\section{Logit Regression Model Specifications}

Statisticians such as Cox (1958) argued that binary (Logit) model is the best fit for the probability of a binary outcome with one or several predictors. The logit model differs from the conventional linear regression and general linear models which employ ordinary least square algorithms such as linearity, homoscedasticity, normality and measurement levels. For instance, the relationship between dependent and independent variables is not required to be linear. From the theoretical framework and the philosophical knowledge in the research methodology a cross-sectional data and Logit regression model has been specified for this study. The crosssectional data and Logit regression model explain the changes and variations in the WTI based on the changes in the independent variables. The model is based on the assumption that the dependent variable is a linear function of the independent variables with an error term (ct). This 
has been illustrated in the equation below. The study has assumed that the relationship between Business Size (BS), Investment Capital (IC), Fixed Assets (FA), Business Stability (BS), Business Ownership (BO), Customer Size (CS), Industrial Structure (IS) and Reinvestment of Annual Profits (RAP) and WTI (WTI) (DY) is a linear function. Thus,

$\operatorname{Logit}(P)=\log (P / 1-P)=\log (p)-\log (1-P)$

This is in the reduced form of a Logit model can be expressed as:

$Y=\alpha+\beta i X i+\varepsilon$

Where:

$W T I_{i}=$ Willingness to Invest

$\alpha=$ The intercept

$\beta_{i}=$ coefficient of independence variables

$\mathrm{X}_{i}=$ independent variables

$\varepsilon_{i}=$ The error term

Model (1)

$$
\begin{gathered}
W T I_{t}=\beta_{0}+\beta_{1} B S_{t}+\beta_{2} I C_{t}+\beta_{3} F A+\beta_{4} B S T_{t}+\beta_{5} B O_{t}+\beta_{6} C S+\beta_{7} I N S_{, t} \\
+\beta_{8} L S_{t}+\beta_{9} L O C_{t}+\beta_{10} R A P_{t}+\varepsilon_{t}
\end{gathered}
$$

\begin{tabular}{|c|c|c|c|}
\hline Constructs/Variables & $\begin{array}{c}\text { Variable } \\
\text { Description }\end{array}$ & $\begin{array}{l}\text { Hypotheses } \\
\text { Effects }\end{array}$ & Variable Sources \\
\hline Dependent & Willingness to invest or not & & \\
\hline Investment Capital & $\begin{array}{l}\text { The value of fixed assets and } \\
\text { liquidity owned by the company } \\
\text { expressed in Ghana cedis }\end{array}$ & $+(-)$ & $\begin{array}{l}\text { Wamono, Kikabi \& } \\
\text { Mugisha (2012); } \\
\text { Stein, Bucci, } \\
\text { Toussaint, Buffie, } \\
\text { Ratsch, Pamer, } \\
\text { Sander \& Xavier } \\
\text { (2013) }\end{array}$ \\
\hline Business stability & $\begin{array}{l}\text { The number of stable years } \\
\text { business has existed usually } \\
\text { expressed in years. }\end{array}$ & $+(-)$ & $\begin{array}{l}\text { Wamono, Kikabi \& } \\
\text { Mugisha (2012); } \\
\text { Kopitov (2013); } \\
\text { Crum \& Nelson } \\
\text { (2015) }\end{array}$ \\
\hline Industrial structure & $\begin{array}{l}\text { The classification of SMEs } \\
\text { industries based on } \\
\text { functionalities. These are } \\
\text { classified into; service, } \\
\text { manufacturing and retailing. }\end{array}$ & $+(-)$ & $\begin{array}{l}\text { Stein, Bucci, } \\
\text { Toussaint, Buffie, } \\
\text { Ratsch, Pamer, } \\
\text { Sander \& Xavier } \\
\text { (2013) Bouazza etal. } \\
\text { (2015) }\end{array}$ \\
\hline Business ownership & $\begin{array}{l}\text { The fact or condition of being the } \\
\text { legal owner of a business entity. } \\
\text { These are classified into } \\
\text { individuals owners or groups }\end{array}$ & $+(-)$ & $\begin{array}{l}\text { Wamono, Kikabi } \\
\text { \&Mugisha (2012); } \\
\text { Kengatharan \& } \\
\text { Clamenthu (2017) }\end{array}$ \\
\hline
\end{tabular}

Table 1. Description of the Variables and Proxies used to Measure WTI 


\begin{tabular}{|c|c|c|c|}
\hline Customer size & $\begin{array}{l}\text { The number of current customers } \\
\text { available to SMEs at a time. } \\
\text { These are expressed as large or } \\
\text { small }\end{array}$ & $+(-)$ & Lutter (2008) \\
\hline Business location & $\begin{array}{l}\text { The site or position of the } \\
\text { business expressed as urban or } \\
\text { rural. }\end{array}$ & $+(-)$ & $\begin{array}{l}\text { Wamono, Kikabi \& } \\
\text { Mugisha (2012); } \\
\text { Plaziak And } \\
\text { Szymansk (2014) }\end{array}$ \\
\hline \multirow[t]{2}{*}{ Business size } & & $+(-)$ & \\
\hline & $\begin{array}{l}\text { The classification of business into } \\
\text { micro, small and medium. }\end{array}$ & & $\begin{array}{l}\text { Weziak-Bialowlska } \\
\text { (2013) }\end{array}$ \\
\hline Fixed assets & $\begin{array}{l}\text { value of fixed assets and liquidity } \\
\text { owned by the company expressed } \\
\text { in Ghana cedis }\end{array}$ & $+(-)$ & $\begin{array}{l}\text { Stein, Bucci, } \\
\text { Toussaint, Buffie, } \\
\text { Ratsch, Pamer, } \\
\text { Sander \& Xavier } \\
\text { (2013); Wamono, } \\
\text { Kikabi \& Mugisha } \\
(2012)\end{array}$ \\
\hline $\begin{array}{l}\text { Reinvestment of annual } \\
\text { profit }\end{array}$ & $\begin{array}{l}\text { The amount of profit a business } \\
\text { owner is willing to re-invest }\end{array}$ & $+(-)$ & $\begin{array}{l}\text { Wamono, Kikabi \& } \\
\text { Mugisha (2012) }\end{array}$ \\
\hline Legal status business & $\begin{array}{l}\text { The legal right or permit to } \\
\text { operate business usually } \\
\text { expressed registered or } \\
\text { unregistered }\end{array}$ & $+(-)$ & $\begin{array}{l}\text { Wamono, Kikabi \& } \\
\text { Mugisha (2012) }\end{array}$ \\
\hline
\end{tabular}

Source: Authors' compilation

\section{Results and discussions}

\section{SMEs Internal Characteristics and WTI}

The Mean age of SMEs Business Stability was 15 (range 10-20), slightly above a third (39.5\%) of the SMEs had exited over 20years and the smaller proportion of the SMEs had operated between 1-10years (36.1\%). The study found a significant difference between business stability and WTI in the oil and gas sector, $\chi^{2}(2, \mathrm{~N}=147)=14.234, \mathrm{p}=.0001$. Regarding business size, majority (42.9\%) were small size business ( $>=5$ and $<=19)$, about one-quarter (26.5) were micro size business $(<5)$, slightly below one-quarter $(23.1)$ were medium size business, $4.1 \%$ were large size business and the least (3.4\%) were the unknown size business. Business size has a significance differences with WTI, $\chi 2(4, \mathrm{~N}=147)=58.815, \mathrm{p}=.000$. Concerning the location of businesses, the majority (72.8\%) was located in the urban areas and the lease $(27.2 \%)$ was located in the Peri-urban areas.

Business location has no significant differences with WTI $\chi 2(4, \mathrm{~N}=147)=.791, \mathrm{p}=$ 374. With reference to business structure, almost half $46.3 \%$ were Sole proprietorship owned business, about one- quarter $17.7 \%$ were limited partnership owned business, $14.3 \%$ ownership each was recorded for a shareholding company with non-traded shares or shares traded privately and Partnership, the least $7.5 \%$ were unclassified business ownership. Business Ownership has a significant differences with WTI $\chi 2(4, \mathrm{~N}=147)=63.455, \mathrm{p}=000$. Slightly below half had $46.3 \%$ small customer size $(<500)$, about a third had $35.4 \%$ had Medium customer size $(>500$ 
$<10000$ ) the least $18.4 \%$ had large customer size (exceeding 1000). Customer size has a significant differences with WTI $\chi 2(2, \mathrm{~N}=147)=7.586, \mathrm{p}=.023$. The majority $(48.3 \%)$ had operated in the retail sector, slightly more than a quarter $(36.7 \%)$ had operated within the service sector and the least $(15.0 \%)$ indicated operations in the Manufacturing.

Industrial structure has a significant differences with WTI $\chi 2(2, \mathrm{~N}=147)=6.050, \mathrm{p}=$ .049. A whopping Majority (96.6\%) had reported legal business status; a scintilla minority (3.7\%) had illegal business registration status. Legal status has no significant differences with WTI $\chi^{2}(1, \mathrm{~N}=147)=1.939, \mathrm{p}=.201$. A large majority $(57.1 \%)$ had investment capital of less than GHC 40,000, and the smaller proportion of the sample (42.9\%) had over GHC50, 000 investment capital. Investment capital has significant differences with WTI $\chi^{2}(6, \mathrm{~N}=147)=$ $92.269, \mathrm{p}=.000$. A vast majority $(92 \%)$ had fixed assets ranging none to GHC40, 000 and the remaining fewer (8\%) had fixed assets of over GHC 40,000. Fixed assets has significant differences with WTI $\chi^{2}(6, \mathrm{~N}=147)=46.297, \mathrm{p}=.000$. SMEs decision to reinvest annual profit significantly affect their WTI $\chi 2(2, \mathrm{~N}=147)=7.47, \mathrm{p}=.029$. Table 1 below presents the details associations between WTI and hypothesized SMEs internal factors.

Table 2. Chi-Square Analysis Results

\begin{tabular}{llcccc}
\hline \multicolumn{2}{c}{ Internal Firm Characteristics } & $\begin{array}{c}\text { Chi-square }\left(\boldsymbol{X}^{2}\right) \\
\text { value }\end{array}$ & Df & P-value & $\begin{array}{c}\text { Hypotheses } \\
\text { Decisions }\end{array}$ \\
\hline H1 & Business stability & $14.234^{\mathrm{a}}$ & 2 & $0.001^{*}$ & Supported \\
\hline H2 & Business ownership & $63.455^{\mathrm{a}}$ & 4 & $0.000^{*}$ & Supported \\
\hline H3 & Customer size & $7.586^{\mathrm{a}}$ & 2 & $0.023^{*}$ & Supported \\
\hline H4 & Industrial Structure & $6.050^{\mathrm{a}}$ & 2 & $0.049^{*}$ & Supported \\
\hline H5 & Legal status & $1.939^{\mathrm{a}}$ & 1 & 0.201 & Rejected \\
\hline H6 & Business Location & $.791^{\mathrm{a}}$ & 1 & 0.374 & Rejected \\
\hline H7 & Business size & $58.815^{\mathrm{a}}$ & 4 & $0.000^{*}$ & Supported \\
\hline H8 & Investment capital & $92.269^{\mathrm{a}}$ & 6 & $0.000^{*}$ & Supported \\
\hline H9 & Fixed Assets & $46.297^{\mathrm{a}}$ & 6 & $0.000^{*}$ & Supported \\
\hline H10 & $\begin{array}{l}\text { Reinvestment of Annual } \\
\text { Profit (s) }\end{array}$ & $7.047^{\mathrm{a}}$ & 2 & $0.029^{*}$ & Supported \\
\hline
\end{tabular}

\section{The Factors that Determine SMEs WTI}

Karl Pearson's chi-square (X2) had been conducted to determine the number of SMEs internal factors that were associated with SMEs WTI in the Ghana oil and gas sector. As indicated in Table 2, business stability (Age), business ownership, customer size, industrial structure are strongly associated with SMEs WTI in the Ghana oil and gas sector. Moreover, business size, investment capital, fixed assets and reinvestment of annual profits are significantly associated with SMEs WTI in the high-value oil and gas sector. Therefore, all the hypotheses are supported except the legal status of business and business location which are not significantly associated with SMEs WTI. The study had further deployed a logistic regression model to measure the directions and contributions of each of the internal factors on the dependent variable (WTI).

\section{The Logistic Regression Model Results}

Logistic regression was conducted to ascertain the effects of business size, investment capital, fixed assets, business stability, business ownership, customer size, industrial structure 
and reinvestment of annual profits on the likelihood that SMEs are willing to invest in the Ghana high-value oil and gas sector. Thus,

$$
\operatorname{Logit}(P)=\log (P / 1-P)=\log (p)-\log (1-P)
$$

The Final Estimated Model is;

$$
\begin{gathered}
\boldsymbol{W T I}=61.2+4.15_{\text {Business Size }}+1.38 \text { Investment Capital }+(-2.79)_{\text {Fixed Assets }}+3.24 \text { Business Stability }+(-8.4)_{\text {Business }} \\
\text { Ownership }+(-11.8)_{\text {Customer Size }}+(-0.33)_{\text {Industrial Structure }}+(-5.86)_{\text {Reinvestment Of Annual Profits }}+ \\
(-9.5)_{\text {Legal Status }}+10.44_{\text {Location }} \text { Eqn. (ii) }
\end{gathered}
$$

From the estimated model above, the coefficients determine the contribution of each independent (predictor) variables in explaining the probability (log old) of occurrence. The Wald statistics were used to validate the significance of the regression coefficients as indicated in table 3 below. The logistic regression model was statistically significant $\chi^{2}(10)=101.64, p$ $<.000$. The explained variation in WTI in the current model ranges from $49.9 \%$ to $83.4 \%$

\begin{tabular}{|c|c|c|c|c|c|c|}
\hline & Parameter & $\beta$ & $\mathbf{S E}$ & Wald & $\operatorname{Exp}(B)$ & P-value \\
\hline $\mathrm{H} 1$ & Business stability & 3.245 & 1.464 & 4.915 & 25.671 & $0.027 *$ \\
\hline $\mathrm{H} 2$ & $\begin{array}{c}\text { Business } \\
\text { ownership } \\
\end{array}$ & -8.402 & 2.946 & 8.133 & .000 & $0.004^{*}$ \\
\hline $\mathrm{H} 3$ & Customer size & -11.830 & 4.230 & 7.820 & .000 & $0.005^{*}$ \\
\hline $\mathrm{H} 4$ & $\begin{array}{l}\text { Industrial } \\
\text { Structure }\end{array}$ & -.332 & 1.490 & .050 & .718 & 0.824 \\
\hline H5 & Legal status & -9.559 & 4.652 & 4.221 & .000 & $0.040^{*}$ \\
\hline H6 & Business Location & 10.444 & 4.141 & 6.361 & 34324.508 & $0.012 *$ \\
\hline $\mathrm{H} 7$ & Business size & 4.153 & 1.905 & 4.753 & 63.616 & $0.029 *$ \\
\hline $\mathrm{H} 8$ & Investment capital & 1.388 & .695 & 3.994 & 4.007 & $0.046^{*}$ \\
\hline $\mathrm{H} 9$ & Fixed Assets & -2.791 & 1.239 & 5.071 & .061 & $0.024^{*}$ \\
\hline $\mathrm{H} 10$ & $\begin{array}{l}\text { Reinvestment of } \\
\text { Annual Profit }\end{array}$ & -5.863 & 2.120 & 7.648 & .003 & $0.006^{*}$ \\
\hline & Constant & 61.210 & 21.454 & 8.140 & 3.830 & $.004 *$ \\
\hline \multicolumn{7}{|c|}{ Model fit Statistics } \\
\hline \multicolumn{3}{|c|}{-2loglikehood( Final model) } & & \multicolumn{2}{|c|}{$32.419 *$} & \\
\hline \multicolumn{3}{|c|}{$X^{2}(\mathrm{df})$ Final Model } & & \multicolumn{2}{|c|}{$101.643 *$} & \\
\hline \multicolumn{3}{|c|}{$\mathrm{X}^{2}(d f)$ Hosmer and Lemeshow Test } & & \multicolumn{2}{|c|}{$21.795^{*}$} & \\
\hline \multicolumn{3}{|c|}{ Cox and Snell $\mathrm{R}^{2}$} & & \multicolumn{2}{|c|}{.499} & \\
\hline \multicolumn{3}{|c|}{ Nagelkerke $\mathrm{R}^{2}$} & & \multicolumn{2}{|c|}{.834} & \\
\hline
\end{tabular}
respectively for Cox and Snell R2 and Nagelkerke R2 and correctly classified $96.6 \%$ of the cases which is a high indication of a good fit for the model.

Table 3. Binary Logistic Regression Analysis Results

Source: Primary data *significant at $95 \%$

\section{Determinants of SMEs WTI as Interpreted from the Model}

This study was carried to ascertain the effects of business size, investment capital, fixed assets, business stability, business ownership, customer size, industrial structure and reinvestment of annual profits on the likelihood that SMEs are willing to invest in the Ghana 
high-value oil and gas sector. From tables 3, the strongest determinants of SMEs WTI were identified as a business location, business stability, investment capital and business size. The positive coefficients imply positive direction with WTI. These results are consistent with previous researchers (Abuka, Egesa, Atai, \& Obwona, 2006; Singh, Garg, \& Deshmukh, 2008; Adusei \& Appiah, 2011; Kira \& He, 2012; Wamono, Kikabi \& Mugisha, 2012; Aylin, Garango, Cocca \& Bititchi, 2013; Sarwoko, Surachman, Aemanu \& Hadiwidjojo, 2013; Bouazza, Ardjouman \& Abada 2015; Quartey, Turkson, Abor \& Iddrisu,2017) who have established a significant linkage between SMEs internal characteristics, growth and performance.

This study had revealed that WTI has been shown to depend on investment capital $(\beta=1.388, \mathrm{p}<0.05)$. This result supports Wamono, Kikabi \& Mugisha, (2012) assertion that investment capital positively and significantly affects SMEs WTI. Relatedly, Kengatharan \&Clamenthu (2017) determined the relationship between capital investment practices and investment decisions of manufacturing companies. The study found significant and positive relationships between present value, internal rate of return and investment decisions. Moreover, Narayansamy, Mohd-Rashid \& Hashemoghli (2012) examined the current practices and the classical venture capital decision model and reported significant similarities between decision making procedure and investment criteria needed to select investment with the classical model. Quartey, Turkson, Abor \& Iddrisu, (2017) further affirm the effects of capital on SMEs growth.

Moreover, WTI is found to depend on business stability $(\beta=3.24, p<0.05)$. The relationship between business stability and WTI has shown that enterprises that have existed for many years have higher WTI as compare to newly start-ups. The effect of business stability on firm investment had been reported by previous researchers (Wamono, Kikabi \& Mugisha, 2012; Sarwoko Surachman, Aemanu \& Hadiwidjojo,2013). Kopitov (2013) and Crum \&Nelson (2015) revealed that business stability has an effect on long time investment. These studies further reported that property right encourages entrepreneurs to invest in new ventures.

The study had revealed that WTI depends on business location $(\beta=10.44, p<0.05)$. The relationship between business location and WTI is such that enterprises with close proximity are had higher WTI than those who operate from their businesses in the peripheries with relatively low connection with oil and gas sector. The business location had been earlier reported as having an association with investment decisions (Abuka, Egesa, Atai, \& Obwona, 2006; Singh, Garg, \& Deshmukh, 2008). For instance, Bakar \& Yi (2016) and Plaziak \&Szymansk (2014) found that business location is a very important factor to consider when setting up a business noting that in addition to other critical factors such as investment requirement and investment climate attraction, business location is a major determinant of investment decisions.

More so, WTI has been shown to depend on the business size $(\beta=4.15, \mathrm{p}<0.05)$. The study had found that an increase in enterprise size has an effect on it WTI. That is SMEs with relatively large size are more willing to invest in the oil and gas sector than those do not. The diverse nature of the oil and gas sector expectedly makes it very cumbersome to micro and small enterprises to invest in the sector. This assertion had been reported earlier by a number of researchers (Blackburn, Hart \& Wainwright, 2013; Al-Matari, Al-Swidi \& Fadzil, 2014; Quartey, Turkson, Abor \& Iddrisu, 2017) supporting that business size has an effect on investment decisions. Meanwhile, Bialowolski \&Weziak-Bialowlska (2013) examined the business size and investment decisions and reported a strong association between business size and investment decisions. Moreover, Lai, Yung-Lung, Feng-Jyh \& Lin,(2015) determined the relationship between company size and investment decision and found that company size is among the important factors that affect corporate investment decisions.

The study also discovered that WTI has inverse and significant relationship with fixed assets $(\beta=-2.791, \mathrm{p}<0.05)$, business ownership $(\beta=-8.402, \mathrm{p}<0.05)$. On the contrary, Nasrum, 
Akal \& Tenri (2013) examined the relationships between ownership structure and corporate investment decisions. This study found that have the significant positive effect of ownership structure and corporate investment decisions. Again, Chen, Guedhami, Ghoul, \& Wang (2014) studied the role of ownership structure in the firm's investment decisions and efficiency. This study found an effect of ownership type on firm-level capital allocation and further reported that foreign ownership investment and efficiency is stronger when government institutions are weaker.

The study found that customer size negatively affects WTI $(\beta=-11.830, p<0.05)$. Lutter (2008) and Keloharju, Knupfer \& Linnainmaa (2012) reported on how customer size affects product to market and investment decisions. Moreover, study also discovered that WTI has inverse and significant relationships with the following; fixed assets $(\beta=-2.791, p<0.05)$, Legal status $(\beta=-9.559, \mathrm{p}<0.05)$ and reinvestment of annual profits $(\beta=-5.863, \mathrm{p}<0.05)$. These findings are important as they negatively affect WTI. It is very imperative for SMEs to do thorough assessments on each of these negative factors to ascertain the magnitude of their effects.

\section{Conclusions and policy implications}

The overall objective of this study has been to examine the impact of SMEs internal characteristics on SMEs investment in the Ghana oil and gas value chain. Precisely, the study explored the following specific objectives: (1) measure associations between WTI in high value oil and gas sector and SMEs internal characteristics (business size, investment capital, fixed assets, business stability, business ownership, customer size, industrial structure, business location, legal status and reinvestment of annual profits); objective (2) predict using SMEs internal characteristics and control for WTI.

To achieve the study objective (1) Pearson's chi-square (X2) goodness of fit has been conducted to determine SMEs internal factors that are associated with SMEs WTI in the Ghana oil and gas sector. The study discovered that business stability, business ownership, customer size, industrial structure are strongly associated with SMEs WTI in the Ghana oil and gas sector. Moreover, business size, investment capital, fixed assets and reinvestment of annual profits are significantly associated with SMEs WTI in the high-value oil and gas sector.

Therefore, all the study hypotheses are supported except the legal status of business and business location which are not significantly associated with SMEs WTI. With regards to the objective (2), Logit regression was conducted to predict SMEs WTI. The study found that that strongest determinants of SMEs WTI in Ghana oil and gas value chain as follows; business location, business stability, investment capital and business size. The positive coefficients imply positive direction with WTI. Also, the logit regression discovered that WTI has inverse and significant relationships with the following factors fixed assets, business ownership, customer size, Legal status and reinvestment of annual profits.

The findings of this study have important policy implications. Since the study has revealed that the strongest determinants of SMEs WTI in Ghana oil and gas value chain are business stability, investment capital business size and business location. This study suggests that SMEs are required to save and invest adequate tangible assets to pledge as collateral to enable them to access external finance in order to increase capital investment, business size and stability. To add to this Quartey, Turkson, Abor \& Iddrisu (2017) had reported that formalization of business is one of the best ways to increase financial access. Better still, the government should ensure SMEs readily access to finance by formulating more relax policies to encourage borrowing from financial institutions (commercial banks, finance companies, micro-finance institutions and other credible sources). Also, the government should act as a 
guarantor for the SMEs to support their financial access. Again, the government through the central bank can create strategic measures to enhance SMEs. Moreover, the government should set up commercial bank purposely to lend to SMEs. SMEs are also encouraged to choose strategic business locations to increase their chances of investing in the oil and gas sector. Finally, we strongly recommend the replication of this study in other emerging oil and gas economies.

\section{Acknowledgement}

"This research received no specific grant from any funding agency in the public, commercial, or not-for-profit sectors."

\section{References}

Abor J., \& Quartey, P. (2010). Issues in SME Development in Ghana and South Africa. International Research Journal of Finance \&Economics, 39, 218-28.

Abuka C.A., K.A Egesa, I. Atai M., \& Obwona (2006). Firm-Level Investment: Trends, determinants and Constraints: Research Series No.47, Economic Policy Research Centre (EPRC), Makerere University, Kampala.

Adusei, M \& Appiah, S, (2011): Determinants of Group Lending in the Credit Union Industry in Ghana. Journal of African Business, 12(2), 238-251, http://DOI:10.1080/15228916.2011.588914

Appiah, K. M., Possumah, B. T., Ahmat, N., Sanusi, N. A. (2018a). External Environment and SMEs Investment in the Ghanaian Oil and Gas Sector. Economics \& Sociology, 11(1), 124-138. http://doi:10.14254/2071-789X.2018/11-1/8

Appiah, K.M., Possumah, B.T., Ahmat, N., \& Sanusi, N.A. (2018b). Applicability of theory of constraint in predicting Ghanaian SMEs investment decisions. Journal of International Studies, 11(2), 202-221. doi:10.14254/2071-8330.2018/11-2/14

Appiah, K.M., Possumah, B.T., Ahmat, N., \& Sanusi, N.A. (2018c). Policy Environment and Small and Medium Enterprises Investment in the Ghanaian Oil and Gas Industry. International Journal of Energy Economics and Policy, 8(4), 244-253.

Australian Government (2011). Key Statistics - Australian Small Business (Department of Innovation, Industry, Science and Research).

Ayyagari, M., Demirgüç-Kunt, A. \& Maksimovic, V. (2011). Small vs. Young Firms Across The World - Contribution to Employment, Job Creation, and Growth, Policy Research Working Paper 5631 (The World Bank Development Research Group).

Aylin, A, Garango, P., Cocca, P., \& Bititchi, U. (2013). The development of SME managerial practice for effective performance management. Journal of small business and enterprise development, 20(1), 28-54, http://DOI:10.1108/14626001311298402

Al-Matari, M. E., Al-Swidi, K. A., \& Fadzil, B. H. F. (2014). The Effect of the Internal Audit and Firm Performance: A Proposed Research Framework. International Review of Management \&Marketing, 4(1), 34-41.

Bakar, S., \& Yi, C.N.A. (2016). The impact of psychological factors on investors decision making in Malaysia stock market: A case study of Klang Valley and Pahang. Economic \& Finance, 35, 319-328, http://doi:10.1016/S2212-5671(16)00040-X

Barney, J. B. (1991). Firm Resources and Sustained Competitive Advantage. Journal of Management, 17(1), 99-120, https://doi.org/10.1177/014920639101700108 
Becherer, C. R. Halstead, D., \& Haynes, P. (2001). Marketing Orientation in SMEs: Effects of the internal environment. Journal of Research in Marketing \& Entrepreneurship, 3(1), 117, http://DOI:10.1108/14715200180001474

Bialowolski, P., \& Weziak-Bialowolska, D. (2013). External Factors Affecting Investment Decisions of Companies. Economics, the open access, open-Assessment journal, 8, 1-21, http://dx.doi.org/10.5018/economics-ejournal.ja.2014-11

Blackburn, R. A. Hart, M., \& Wainwright, T. (2013). Small business performance: business, strategy and owner-manager characteristics. Journal of Small Business and Enterprise Development, 20(1), 8-27, https://doi.org/10.1108/14626001311298394

Bouazza, B. A., Ardjouman, D., \& Abada, O. (2015). Establishing the Factors Affecting the Growth of Small and Medium-sized Enterprises in Algeria. American International Journal of Social Science, 4(2), 101-115.

Chen, R., Guedhami, O., Ghoul, E.S., \& Wang, H. (2014). Do state and foreign ownership affect investment efficiency? Evidence from privatizations. Journal of Corporate Finance, 42, 408-421, http://DOI:10.1016/j.jcorpfin.2014.09.001

Ciavarella, M., Buchholt, A., Riordan, C., Gatewood, R., \& Stokes, G. (2004). The Big Five and Venture Survival: Is There a Linkage?. Journal of Business Venturing, 19(4), 465493, http://doi:10.1016/j.jbusvent.2003.03.001

Connor, T. (2002). The resource-based view of strategy and its value to practising managers. Strategic Change, 11(6), 307-316, https://doi.org/10.1002/jsc.593

Crum, M., \& Nelson, E.T. (2015). Stabilizing institutions for new venture investment decisions. Journal of Enterprising Communities: People and Places in the Global Economy, 9(4), 344-360, https://doi.org/10.1108/JEC-05-2013-0014

Dalberg (2011). Report on Support to SMEs in Developing Countries Through Financial Intermediaries, SME Briefing Paper, EIB Draft Version (Geneva: European Investment Bank).

Dierickx, I., \& Cool, K. (1989) Asset stock accumulation and sustainability of competitive advantage. Management Science, 35(12), 1504-1511.

Dragnić, D. (2014). Impact of internal and external factors on the performance of fast-growing small. Management, 19(1), 119-159.

EIU (Economist Intelligence Unit) (2010). SMEs in Japan: A New Growth Driver?

Eurostat (2011). Key Figures on European Business - With a Special Feature on SMEs, Eurostat Pocketbooks (European Commission).

Eze, C. S., Okoye, C. J., Nebo, G. O., Ohakwe, N. S., Chukwuemeka, E., \& Anazodo, R. (2011). Using the Characteristics of Small Business Managers to Understand Information Technology (IT) Adoption in Nigeria. International Journal of Business and Social Science, 2(13), 82-90.

Flynn, B. B., Sakakibara, S., Schroeder, R. G., Bates, K. A., \& Flynn, E. J. (1990). Empirical Research Methods in Operations Management. Journal of Operations Management, 9(2), 250-284, http://DOI:10.1016/0272-6963(90)90098-X

Fox, W., \& Bayat, M.S. (2007). A Guide to Managing Research. Juta Publications.

Gravetter, F.J., \& Forzano, L.B. (2011). Research Methods for the Behavioural Sciences. Cengage Learning.

Hair, F. Sarstedt, M., Hopkins, L., \& Kuppelwieser, V. (2014). Partial least squares structural equation modeling (PLS-SEM): An emerging tool for business research. European Business Review, 26(2), 106-121, DOI: 10.1108/EBR-10-2013-0128

Keloharju, M., Knüpfer, S., \& Linnainmaa, J. (2012). Do investors buy what they know? Product market choices and investment decisions. The Review of Financial Studies, 25(10), 2921-2958, http://doi:10.1093/rfs/hhs090 
Kengatharan, L., \& Clamenthu, D.P. (2017). Use of Capital Investment Appraisal Practices and Effectiveness of Investment Decisions: A Study on Listed Manufacturing Companies in Sri Lanka. University of Jaffna.

Kira, R. A., \& He, Z. (2012). The Impact of Firm Characteristics in Access of Financing by Small and Medium-sized Enterprises in Tanzania. International Journal of Business and Management, 7(24), 108-119, http://DOI:10.5539/ijbm.v7n24p108

Kopitov, R. (2013). Enhancing business sustainability: improving business policy's methodology by managerial principles development. Procedia - Social and Behavioral Sciences, 99, 133-142, https://doi.org/10.1016/j.sbspro.2013.10.479

Kozlowski, R., \& Matejun, M. (2016). Characteristic Features of Project Management in Small and Medium-Sized Enterprises. Business Administration and Management, 1, XIX, 3348, http://doi:10.1524/tul/001/2016-1-003

Kozubíková, L., Belás, J., Bilan, Y., \& Bartoš, P. (2015). Personal characteristics of entrepreneurs in the context of perception and management of business risk in the SME segment. Economics and Sociology, 8(1), 41-54, http://DOI:10.14254/2071789X.2015/8-1/4

Lai, Yung-Lung \& Lin, Feng-Jyh, \& Lin, Yi-Hsin, (2015). Factors affecting the firm's R\&D investment decisions. Journal of Business Research, 68(4), 840-844, http://dx.doi.org/10.1016/j.jbusres.2014.11.038

Lutter, J.L. (2008). Consumer behaviour during investment gold purchase in comparison to other investment instruments. Tallin University.

Morse, E.A., Fowler, S.W., \& Lawrence, T.B. (2007). The impact of virtual embedded on new venture survival: Overcoming the liabilities of newness. Entrepreneurship Theory \& Practice, 31(2), 139-159, https://doi.org/10.1111/j.1540-6520.2007.00167.x

Narayansamy, C., Mohd-Rashid, R., \& Hashemoghli, A. (2012). Ventures capital preinvestment decision-making process: An exploratory study in Malaysia. Global Journal of Business Research, 6(5), 49-63.

Nasrum, M., Akal, U., \& Tenri, A. (2013). The Influence of Ownership Structure and Corporate Governance to Investment Decision Companies Listed on Indonesia Stock Exchange. International journal of science and research (IJSR), 4(2), 864-866, http://DOI:10.12816/0018978

OECD. (2009a). Top Barriers and Drivers to SME Internationalisation, Report by the OECD Working Party on SMEs and Entrepreneurship. www.oecd.org/industry/smes/43357832.pdf

OECD. (2009b). The Impact of the Global Crisis on SME and Entrepreneurship Financing and Policy Responses www.oecd.org/industry/smes/43183090.pdf

OECD. (2012). Financing SMEs and Entrepreneurs: An OECD Scoreboard, OECD, Paris www.keepeek.com/Digital-Asset-Management/oecd/industry-and-services/financingsmes-and-entrepreneurship_9789264166769-en

Olawale, F., \& Garwe, D. (2010). Obstacles to the growth of new SMEs in South Africa: A principal component analysis approach. African Journal of Business and Management, 4(5), 729-738.

Osei, B., Baah-Nuakoh, A., Tutu, K., \& Sowa, N., (1993). Impact of structural adjustment on small-scale enterprises in Ghana. In: Helmsing, A., Kolstee, T. (Eds.).Small Enterprise and Changing Policies: Structural Adjustment, Financial Policy and Assistance Programmes in Africa. IT Publications, London, pp. 53-70.

Oyejide, T. A., \& Adewuyi, A. O. (2011). Enhancing linkages of the oil and gas industry in the Nigerian economy. MMCP Discussion Paper No. 8. 
Pasanen, M. (2007). SME growth strategies: organic or non-organic?. Journal Enterprising Culture, 15(04), 317-338, https://doi.org/10.1142/S0218495807000174

Peteraf, M. A. (1993). The Cornerstones of Competitive Advantage: a Resource-Based View. Strategic Management Journal, 14(3), 179-191, https://doi.org/10.1002/smj.4250140303

Plaziak, M., \& Szymansk, A.I. (2014). Importance of Personal Factor in Decisions on Locating Enterprises. Procedia - Social and Behavioral Sciences, 110, 373-380, http://DOI:10.1016/j.sbspro.2013.12.881

Possumah, T. B., \& Appiah, K. M. (2018). Institutional support in managerial capacity building and Ghanaian SMEs growth: The mediating effect of marketing orientation. Jurnal Ekonomi Malaysia, 52(3), 231-243.

Possumah, B. T., Appiah, M. K., \& Hilmiyah, N. (2018). Determinants of Islamic banking adoption across different religious groups in Ghana: A panoptic perspective. Journal of International Studies, 11(4), 138-154. doi:10.14254/2071-8330.2018/11-4/10

Pullen, A., de Weerd-Nederhof, P., Groen, A., Song, M., \& Fisscher, O. (2009). Successful Patterns of Internal SME Characteristics Leading to High Overall Innovation Performance. Creativity and Innovation Management, 18(3), 209-223, http://doi:10.1111/j.1467-8691.2009.00530.x

Quartey, P., Turkson, E., Abor, J.Y. \& Iddrisu A.M. (2017). Financing the growth of SMEs in Africa: What are the constraints to SME financing within ECOWAS?. Review of Development Finance, 7(1), 18-28, https://doi.org/10.1016/j.rdf.2017.03.001

Rumelt, R. P. (1984). Toward a Strategic Theory of the Firm', in Lamb, R. (Eds.). Competitive Strategic Management, 26, 556-570. Englewood Cliffs, NJ: Prentice Hall.

Saunders, M., Lewis, P. \& Thornhill, A. (2012). Research Methods for Business Students. $6^{\text {th }}$ edition, Pearson Education Limited.

Sarwoko, E., Surachman, Armanu, \& Hadiwidjojo, D. (2013). Entrepreneurial Characteristics and Competency as Determinants of Business Performance in SMEs. IOSR Journal of Business and Management (IOSR-JBM), 7(3), 31-38.

Sidika, I. (2012). The conceptual framework of factors affecting SME development: Mediating factors on the relationship of entrepreneur traits and SME performance. Proceedings from ICSMED 2012: International Conference on Small and Medium Enterprises Development. Procedia Economics and Finance, 4, 373 -383, https://doi:10.1016/S2212$\underline{5671(12) 00351-6}$

Singh, R., Garg, S. \& Deshmukh, G.S. (2008) Strategy development by SMEs for competitiveness: A review. Benchmarking: an International Journal, 15(5), 525-547, https://doi.org/10.1108/14635770810903132

Stein, R. R., Bucci, V., Toussaint, N. C., Buffie, C. G., Ratsch, G., Pamer, E. G., Sander, C., \& Xavier, B. J. (2013). Ecological Modeling from Time-Series Inference: Insight into Dynamics and Stability of Intestinal Microbiota. PLoSComputBiol, 9(12), 1-11 e1003388. https://doi.org/10.1371/journal.pcbi.1003388

Wamono, R. N., Kikabi, P. \& Mugisha, J. (2012). Constraints and Opportunities for SMEs Investment in Uganda's Oil and Gas Sector, Investment Climate and Business Environment Research Fund (ICBE-RF). Uganda Investment Authority, Kampala, Uganda.

Wernerfelt, B. (1984). A Resource-based View of the Firm. Strategic Management Journal, 5(2), 171-180.

World Bank. (2015). World Development Indicators.

Zikmund, W.G., Babin, J., Carr, J. \& Griffin, M. (2012). Business Research Methods: with Qualtrics Printed Access Card, Cengage Learning. 